\title{
Berberine hydrochloride IL-8 dependently inhibits invasion and IL-8-independently promotes cell apoptosis in MDA-MB-231 cells
}

\author{
XIANG LI $^{1 *}$, SHU-JUAN ZHAO ${ }^{1 *}$, HAI-LIAN SHI ${ }^{1,2}$, SHUI-PING QIU $^{1}$, JIAN-QUN XIE ${ }^{2}$, \\ HUI WU ${ }^{1}$, BEI-BEI ZHANG ${ }^{1}$, ZHENG-TAO WANG $^{1}$, JIAN-YE YUAN ${ }^{2}$ and XIAO-JUN WU ${ }^{1}$ \\ ${ }^{1}$ Shanghai Key Laboratory of Complex Prescription, Institute of Chinese Materia Medica, The Ministry of \\ Education (MOE) Key Laboratory for Standardization of Chinese Medicines, Shanghai University of Traditional Chinese \\ Medicine, Zhangjiang Hi-tech Park, Shanghai 201203; ${ }^{2}$ Institute of Digestive Disease, Longhua Hospital, \\ Shanghai University of Traditional Chinese Medicine, XuHui, Shanghai 200032, P.R. China
}

Received June 13, 2014; Accepted August 12, 2014

DOI: $10.3892 /$ or.2014.3520

\begin{abstract}
Breast cancer, the leading cause of cancer-related mortality worldwide in females, has high metastastic and recurrence rates. The aim of the present study was to evaluate the anti-metastatic and anticancer in situ effect of berberine hydrochloride (BER) in MDA-MB-231 cells. BER dose-dependently inhibited proliferation and the IL-8 secretion of MDA-MB-231 cells. Additional experiments revealed that the inactivation of PI3K, JAK2, NF- $\kappa$ B and AP-1 by BER contributed to the decreased IL- 8 secretion. BER abrogated cell invasion induced by IL- 8 accompanied with the downregulation of the gene expression of MMP-2, EGF, E-cadherin, bFGF and fibronectin.
\end{abstract}

Correspondence to: Dr Hai-Lian Shi or Dr Xiao-Jun Wu, Shanghai Key Laboratory of Complex Prescription, Institute of Chinese Materia Medica, The Ministry of Education (MOE) Key Laboratory for Standardization of Chinese Medicines, Shanghai University of Traditional Chinese Medicine, 1200 Cailun Road, Zhangjiang Hi-tech Park, Shanghai 201203, P.R. China

E-mail: shihailian2003@163.com

E-mail: xiaojunwu320@126.com

*Contributed equally

Abbreviations: BER, berberine hydrochloride; DMSO, dimethyl sulfoxide; PI, propidium iodine; FBS, fetal bovine serum; CCK-8, Cell Counting Kit-8; TBST, Tris-HCl-buffered saline with Tween-20; SDS-PAGE, sodium dodecyl sulfate polyacrylamide gel electrophoresis; PBS, phosphate-buffered saline; RT, room temperature; IL-8, interleukin-8; PCR, polymerase chain reaction; ELISA, enzymelinked immunosorbent assay; JAK, Janus-activated kinase; MAPK, mitogen-activated protein kinase; SAPK/JNK, stress-activated protein kinase/c-Jun N-terminal kinase; ERK, extracellular-regulated protein kinases; NF- $\mathrm{BB}$, nuclear factor $\kappa$-light-chain-enhancer of activated $\mathrm{B}$ cells; GAPDH, glyceraldehyde 3-phosphate dehydrogenase; PI3K, phosphatidylinositol 3 kinase; MMP-2, matrix metalloproteinase-2; EGF, epidermal growth factor; bFGF, basic fibroblast growth factor; Akt, serine/threonine kinase; AP-1, activator protein 1

Key words: berberine hydrochloride, proliferation, metastasis, apoptosis, interleukin-8, MDA-MB-231 cells, breast cancer
In addition, BER reduced cell motility but induced G2/M arrest and cell apoptosis in an IL-8-independent manner. BER modulated multiple signaling pathway molecules involved in the regulation of cell apoptosis, including activation of p38 MAPK and $\mathrm{JNK}$ and deactivation of JAK2, p85 PI3K, Akt and NF- $\mathrm{BB}$. The enhanced cell apoptosis induced by BER was eliminated by inhibitors of p38 MAPK and JNK but was strengthened by activator of p38 MAPK. Thus, BER inhibited cell metastasis partly through the IL- 8 mediated pathway while it induced G2/M arrest and promoted cell apoptosis through the IL-8 independent pathway. Apoptosis induced by BER was mediated by crosstalks of various pathways including activation of p38 MAPK and JNK pathways and inactivation of JAK2/ $\mathrm{PI} 3 \mathrm{~K} / \mathrm{NF}-\kappa \mathrm{B} / \mathrm{AP}-1$ pathways. The results suggested that BER may be an efficient and safe drug candidate for treating highly metastatic breast cancer.

\section{Introduction}

Breast cancer, the leading cause of cancer-related mortality worldwide in females, has high metastastic and recurrence rates following curative resection. Metastasis after resection, is the leading cause of mortality in patients with breast cancer $(1,2)$. Interleukin-8 (IL-8), a cytokine of the CXC chemokine family (3), is highly expressed in many tumor tissues (4) and promotes tumor progression and cancer metastasis (5-10). Findings of recent studies have shown that the overexpression of IL-8 is associated with recurrence and poor prognosis in breast cancer (11-14). The expression of IL-8 in highly metastatic breast cancer MDA-MB-231 cells is much higher than that in the non-metastatic MCF-7 breast cancer cell line $(15,16)$. Recent studies have demonstrated that, during or after treatment, several chemotherapeutic drugs resulted in resistance and cancer metastasis associated with upregulated IL-8 in human breast cancer (17-20). Thus, suppression of IL-8 may be beneficial for breast cancer treatment.

Chemotherapeutic agents, such as 5-fluorouracil, adriamycin, dacarbazine and paclitaxel can induce IL-8 upregulation (5,21-25). Coptis chinensis Franch (Huanglian), a medicinal herb, induces cell growth arrest and apoptosis in human breast cancer cells (26). Berberine, an active isoquino- 
line alkaloid in $C$. chinensis, shows anti-metastatic activity in breast cancer cells including MDA-MB-231 and MCF-7 cells (27). In the clinic, berberine hydrochloride (BER) with better water solubility than berberine, is used to treat gastrointestinal inflammation, bacterial diarrhea or infection as well as some gastrointestinal cancers $(10,28,29)$. In our previous studies, BER inhibited the proliferation and IL- 8 expression of AGS cells and counteracted enhanced IL- 8 induced by evodiamine in AGS cells $(10,30)$. However, the effect of berberine and BER on IL-8 expression and the relationship of IL- 8 with migration and cell proliferation in MDA-MB-231 cells remains to be determined.

Induction of apoptosis of cancer cells, mainly through the mitochondrial- and death receptor-dependent pathways, is the principal strategy for chemotherapy. In addition, several other pathways involved in cell apoptosis are influenced by chemotherapeutic drugs (31-33). Berberine has been demonstrated to induce apoptosis of cancer cells including SW60 and HepG2 cells by interfering with the expression of molecules in pathways including Bcl-2, Bax and caspase-3 (34-36). However, whether these pathways play a role in BER-induced apoptosis in breast cancer cells remains to be clarified.

In the present study, the effects of BER on IL-8 expression, and the migration, invasion and cell proliferation of MDA-MB-231 cells were investigated. Furthermore, the possible molecular mechanisms involved in the anti-metastatic and pro-apoptotic effect of BER were discussed. The results suggested that BER may be an efficient and safe drug candidate for treating highly metastatic breast cancer.

\section{Materials and methods}

Materials and chemicals. Berberine hydrochloride (BER, purity: $98 \%$, no. 8892010) was purchased from Shanghai Tauto Biotech Co., Ltd. (Shanghai, China). Dulbecco's modified Eagle's medium (DMEM)/high-glucose medium was obtained from Cellgro (Manassas, VA, USA). Trypsin (no. 1310929) and FBS (no. 1301838) were provided by Gibco (Grand Island, NY, USA). Propidium iodine (PI) (no. 118 K3583) and dimethyl sulfoxide (DMSO) (no. RNBC 3642) were supplied by Sigma Chemical Co. (St. Louis, MO, USA). The primers for qPCR, TRIzol (no. 66205) and Annexin V-FITC (no. 1081948) were from Invitrogen (Carlsbad, CA, USA). Cell Counting Kit-8 (no. ET758) was provided by Dojindo Laboratories (Kumamoto, Japan). SYBR Premix Ex Taq (no. AK2902) and PrimeScript RT reagent kit (no. AK2001) were from Takara (Dalian, China). IL-8 ELISA kit (no. E15164-105) was obtained from eBioscience (San Diego, CA, USA). Human IL-8 (no. 120219) was purchased from PeproTech (Rocky Hill, NJ, USA). The ECL Prime kit (no. 4618945) was purchased from GE Healthcare (Buckinghamshire, UK). Anti-GAPDH (no. 8), anti-p38 MAPK (no. 4), anti-ERK(1/2) (no. 14), anti-JNK (no. 9), anti-p85 PI3K (no. 4), anti-p65 NF-кB (no. 1), anti-Jak2 (no. 8), anti-p-p38 MAPK (no. 10), anti-p-ERK(1/2) (no. 14), anti-p-JNK (no. 9), anti-p-p85 PI3K (no. 2), anti-p-p65 NF-кB (no. 6), anti-p-Jak2 (no. 10), anti-p-Akt (T308, no. 17), and antip-Akt (S473, no. 13) antibodies were supplied by Cell Signaling Technology (Danvers, MA, USA). Anti-Akt (no. YE121003), and anti-cleaved caspase-3 (no. YJ010604C) antibodies were supplied by Epitomics (Burlingame, CA, USA). JAK inhibitor I
(Jak inhibitor, no. D3010), LY294002 (PI3K inhibitor), and SB203580 (p38 MAPK inhibitor, no. C3110) were purchased from Santa Cruz Biotechnology Inc. (Santa Cruz, CA, USA). Curcumin (AP-1 inhibitor) was obtained from ICN Biomedicals Inc. (Costa Mesa, CA, USA). BAY-11-7082 (NF- $\kappa \mathrm{B}$ inhibitor, no. 01), SP600125 (JNK inhibitor, no. 01), PD98059 (ERK1/2 inhibitor, no. 03) were obtained from Selleck Chemicals (Houston, TX, USA). Anisomycin (activitors of p38 MAPK and JNK, no. D00140631) was from Calbiochem (San Diego, CA, USA).

Proliferation assay. MDA-MB-231 cells were cultured in DMEM with $10 \%$ fetal bovine serum (FBS). The cells were seeded in $200 \mu \mathrm{l}$ of medium at $1.0 \times 10^{4}$ cells $/ \mathrm{ml}$ in 96 -well culture plates and grown overnight. Following treatment with BER for 24 or $48 \mathrm{~h}$, respectively, the culture medium was collected for ELISA assay of IL-8. An equal volume of fresh medium was then added back to each well with an additional $20 \mu \mathrm{l}$ of CCK-8 solution and incubated at $37^{\circ} \mathrm{C}$ for another $1 \mathrm{~h}$. Absorbance of the dissolved solutions was detected at $450 \mathrm{~nm}$ by a Thermo Scientific Varioskan Flash microplate reader (Thermo Fisher Scientific). The cell viability rate was calculated as: (absorbance of drug-treated sample/absorbance of control sample) x 100.

Enzyme-linked immunosorbent assay (ELISA). Cells were seeded in 96-well, 6-well or 35-mm plates and cultured overnight. Following treatment with BER for 24 or $48 \mathrm{~h}$, the culture medium was collected, centrifuged at $3000 \mathrm{rpm}$ for $5 \mathrm{~min}$ and subjected to IL-8 assay using an ELISA kit according to the manufacturer's instructions. The absorbance at $450 \mathrm{~nm}$ was measured with a microplate reader, and the concentration of IL-8 in medium was determined by the standard curve.

Wound-healing assay. MDA-MB-231 cells were seeded in 24-well plates. After the cells reached 90-95\% confluence, a scratch was drawn on the cell monolayer with a sterile $100 \mu \mathrm{l}$ pipette tip. The detached cells were removed by washing with PBS. Treatments of BER (30,60 and $90 \mu \mathrm{M})$ and IL-8 $(100 \mathrm{ng} / \mathrm{ml})$ prepared in medium were added onto the cells and the images were captured immediately under an Olympus CKX41 microscope (Olympus, Tokyo, Japan) and denoted as time T0. Following incubation for 24 and $48 \mathrm{~h}$, the cells were photographed again and denoted as time T24 and T48.

Invasion assay. The invasion ability of breast cancer cells was evaluated according to the methods described by Kuo et al (27). Briefly, $200 \mu 1$ of MDA-MB-231 cells (1x10 cells in serum-free medium) were seeded onto the upper part of the 24-well Transwell chambers coated with Matrigel (BD Biosciences, San Jose, CA, USA). FBS (10\%) was used as the chemoattractant in the bottom chambers. After incubation with IL-8 $(100 \mathrm{ng} / \mathrm{ml})$, BER $(90 \mu \mathrm{M})$ or their combination at $37^{\circ} \mathrm{C}$ for $24 \mathrm{~h}$, the non-invaded cells were removed from the top of the Transwell membrane with a cotton swab. The invaded cells were fixed with $4 \%$ PFA for $10 \mathrm{~min}$, followed by incubation with $2 \%$ crystal violet staining solution for $15 \mathrm{~min}$, and were observed under an Olympus CKX41 microscope.

Quantitative polymerase chain reaction ( $q P C R$ ). Total RNA was extracted from the MDA-MB-231 cells using TRIzol 
Table I. Primer sequences used in qPCR.

\begin{tabular}{llc}
\hline Genes & \multicolumn{1}{c}{ Forward primer } & Reverse primer \\
\hline GAPDH & GCACCGTCAAGGCTGAGAAC & TGGTGAAGACGCCAGTGGA \\
E-cadherin & CGAGAGCTACACGTTCACGG & GGGTGTCGAGGGAAAAATAGG \\
Fibronectin & TGAGCTGCACATGTCTTG & TCCTACGTGGTATGTCTTCC \\
bFGF & GGCGTGTACATGTGGTCTCAGA & TTATGGCTCACTGCAACCTTGA \\
EGF & GACTTGGGAGCCTGAGCAGAA & CATGCACAAGTGTGACTGGAGGT \\
MMP-2 & TGGCAAGTACGGCTTCTGTC & TTCTTGTCGCGGTCGTAGTC \\
Jak 2 & TCTGGGGAGTATGTTGCAGAA & AGACATGGTTGGGTGGATACC \\
Akt1 & CCTCCACGACATCGCACTG & TCACAAAGAGCCCTCCATTATCA \\
\hline
\end{tabular}

reagent according to the manufacturer's instructions. Reverse transcription was conducted with a PrimeScript RT reagent kit. Sense and antisense primers used for qPCR were shown in Table I. qPCR was performed with SYBR Premix Ex Taq by using following amplification conditions: $95^{\circ} \mathrm{C}$ for $30 \mathrm{sec}$; followed by 40 cycles $\left(95^{\circ} \mathrm{C}\right.$ for $5 \mathrm{sec} ; 60^{\circ} \mathrm{C}$ for $\left.34 \mathrm{sec}\right)$; and $95^{\circ} \mathrm{C}$ for $15 \mathrm{sec} ; 60^{\circ} \mathrm{C}$ for $1 \mathrm{~min}$; and $95^{\circ} \mathrm{C}$ for $15 \mathrm{sec}$. The relative expression level of individual genes was normalized to that of GAPDH in the same sample.

Cell cycle distribution analysis. Cells were seeded in 6-well plates at $6 \times 10^{4}$ cells/well in $3 \mathrm{ml}$ medium and cultured overnight. After serum starvation for $24 \mathrm{~h}$, the cells were incubated with BER (30, 60 and $90 \mu \mathrm{M}), \mathrm{IL}-8(100 \mathrm{ng} / \mathrm{ml})$ or a combination of IL-8 and BER $(90 \mu \mathrm{M})$ for $24 \mathrm{~h}$. The cells were harvested by trypsinization, washed twice with phosphate-buffered saline (PBS), and fixed with cold $70 \%$ ethanol overnight followed by staining with PI solution containing $50 \mu \mathrm{g} / \mathrm{ml}$ RNase A and $0.1 \%$ Triton $\mathrm{X}-100$. The distribution of the cell cycle was examined using a Millipore Guava flow cytometer (Millipore, Billerica, MA, USA).

Cell apoptosis detection. Cells were seeded in 6-well plates at $7.5 \times 10^{4}$ cells/well in $3-\mathrm{ml}$ medium and allowed to adhere to plates overnight. After serum starvation for $24 \mathrm{~h}$, the cells were incubated with a range of concentrations of BER (30, 60 and $90 \mu \mathrm{M}$ ) with $10 \%$ FBS for another $24 \mathrm{~h}$. In experiments for clarifying cell signaling pathways involved in BER-induced apoptosis, the cells were treated with BER at $90 \mu \mathrm{M}$ for $24 \mathrm{~h}$ after pre-incubation of SB203580 $(25 \mu \mathrm{M}), \mathrm{LY} 294002(10 \mu \mathrm{M})$, SP600125 $(20 \mu \mathrm{M})$, PD98059 $(20 \mu \mathrm{M})$, BAY-11-7082 $(5 \mu \mathrm{M})$, JAK inhibitor I $(5 \mu \mathrm{M})$, curcumin $(8 \mu \mathrm{M})$ and anisomycin $(10 \mu \mathrm{g} /$ $\mathrm{ml}$ ) for $1 \mathrm{~h}$. The cells were subsequently harvested by careful trypsinization, and washed twice with $1 \mathrm{X}$ Annexin $\mathrm{V}$ binding buffer. After resuspension in $1 \mathrm{X}$ Annexin $\mathrm{V}$ binding buffer, the cells were stained with Annexin V and PI. Fluorescence of the cells was examined on a Guava flow cytometer.

Western blotting. After incubation with BER, the cells were lysed with lysis buffer and sonicated three times each for $15 \mathrm{sec}$. The cell lysate was centrifuged at $14,000 \mathrm{x}$ g for $15 \mathrm{~min}$ at $4^{\circ} \mathrm{C}$, and the supernatant was collected. Protein samples were sepa- rated by SDS-PAGE (12 or 15\%) and transferred onto PVDF membrane by wet transfer. PVDF membranes were blocked with $5 \%$ non-fat milk solution and incubated with different primary antibodies overnight at $4^{\circ} \mathrm{C}$. After being washed with 1X TBST, PVDF membranes were incubated with respective secondary antibodies. The protein bands were visualized with ECL Prime kit.

Statistical analysis. Each value was presented as means \pm SEM. Differences between two groups were analyzed using Student's t-test. Pairwise comparisons among groups were conducted by one-way ANOVA with Dunnett's analysis using PrismDemo 4. $\mathrm{P}<0.05$ was considered statistically significant.

\section{Results}

$B E R$ inhibits proliferation and $I L-8$ secretion of $M D A-M B-$ 231 cells. To examine the efficacy of BER on cell growth of breast cancer, MDA-MB-231 cells were treated with a range of concentrations of BER for 24 and $48 \mathrm{~h}$, respectively. As shown in Fig. 1B, BER dose-dependently inhibited the proliferation of MDA-MB-231 cells at 24 or $48 \mathrm{~h}$. When used at concentrations of $>90 \mu \mathrm{M}$ for $24 \mathrm{~h}$, BER suppressed the growth of cells, and the growth inhibitory rate of was $>44.18 \%$. By contrast, when treated for $48 \mathrm{~h}$, at lower concentrations, such as $60 \mu \mathrm{M}$, BER prevented $38.94 \%$ of cells from proliferation. Accordingly, the $\mathrm{IC}_{50}$ of BER was $78.21 \mu \mathrm{M}$ for 24-h treatment, while that for $48 \mathrm{~h}$ was $71.87 \mu \mathrm{M}$.

Further analysis demonstrated that BER significantly decreased the IL-8 secretion of MDA-MB-231 cells in a dosedependent manner (Fig. 1C). To determine cellular signaling molecules involved in the modulation of IL- 8 secretion of MDA-MB-231 cells, multiple pathway inhibitors were used, including LY294002 (10 $\mu \mathrm{M})$, SB203580 (25 $\mu \mathrm{M})$, SP600125 (20 $\mu \mathrm{M})$, PD98059 $(20 \mu \mathrm{M})$, BAY-11-7082 (5 $\mu \mathrm{M})$, JAK inhibitor I $(5 \mu \mathrm{M})$ and curcumin $(8 \mu \mathrm{M})$. As shown in Fig. 1D, these inhibitors were able to decrease the IL- 8 secretion of MDA-MB-231 cells compared with the control group. Furthermore, pre-incubation with the above mentioned inhibitors, with the exception of the AP-1 inhibitor, increased the inhibitory effect of BER $(90 \mu \mathrm{M})$ on IL-8 expression in MDA-MB-231 cells. 
$\mathbf{A}$<smiles>COc1ccc2cc3c(cc2c1OC)CCc1cc2c(cc1-3)OCO2</smiles>

C

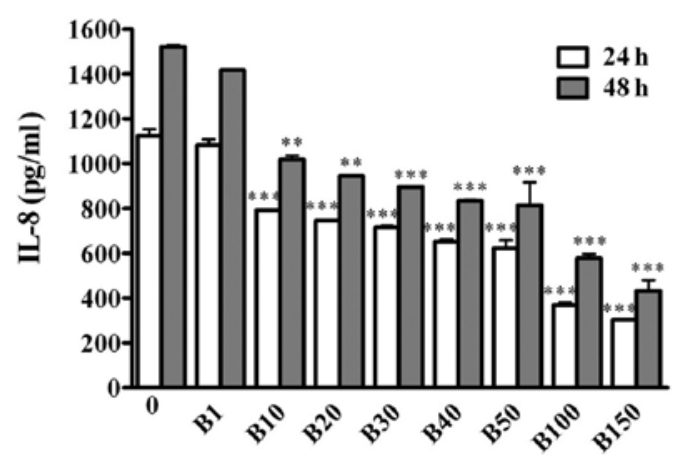

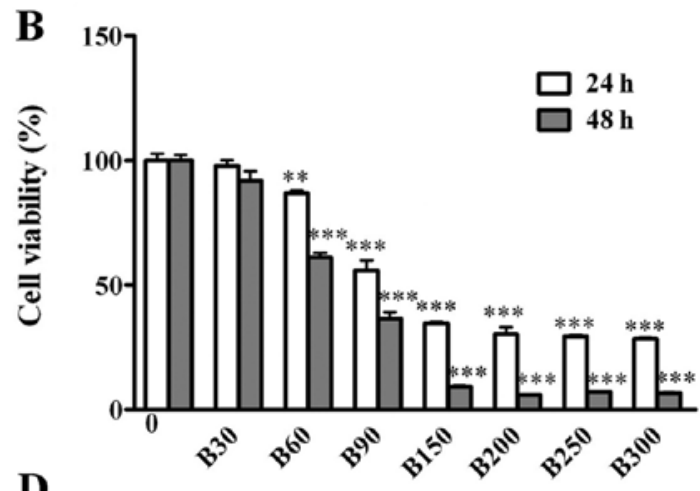

D

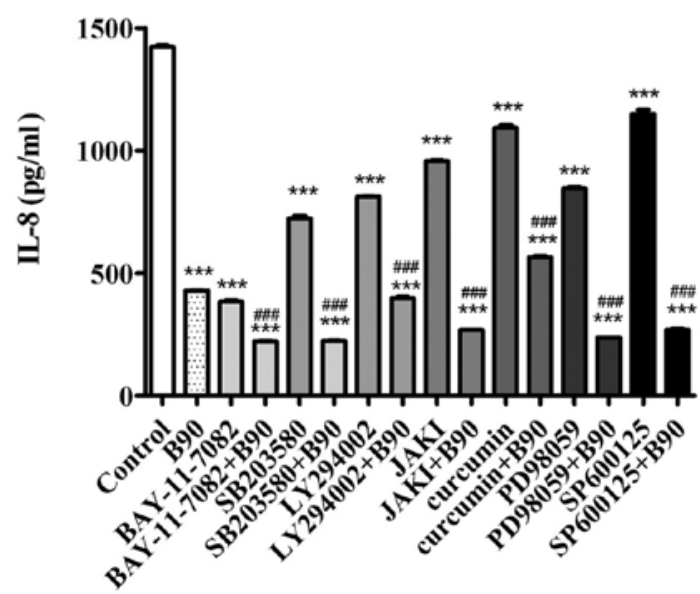

Figure 1. BER inhibits cell proliferation and IL-8 secretion of MDA-MB-231 cells. (A) Chemical structure of BER. (B) MDA-MB-231 cells were treated with $0.1 \%$ DMSO or BER (30-300 $\mu \mathrm{M})$ for 24 and $48 \mathrm{~h}$, then measured by CCK-8 assay to determine the cell viability. (C) IL-8 secretion was detected by ELISA following BER treatment (1-150 $\mu \mathrm{M})$ for 24 and $48 \mathrm{~h}$, respectively. (D) MDA-MB-231 cells were pre-incubated with or without inhibitors of cell signaling pathways (BAY-11-7082, $5 \mu \mathrm{M}$; SB203580, $25 \mu \mathrm{M}$; LY294002, $10 \mu \mathrm{M}$; JAK I, $5 \mu \mathrm{M}$; Curcumin, $8 \mu \mathrm{M}$; PD98059, $20 \mu \mathrm{M}$; and SP600125, $20 \mu \mathrm{M}$ ) for $1 \mathrm{~h}$, followed by B90 treatment for $24 \mathrm{~h}$. IL-8 level in culture serum was measured by ELISA. Data are presented as means $\pm \mathrm{SEM} ;{ }^{* *} \mathrm{P}<0.01,{ }^{* * * *} \mathrm{P}<0.001 \mathrm{vs}$. control.

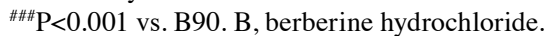

BER decreases cell invasion and migration of MDA-MB-231 cells. In order to clarify the relationship between BER and cell metastasis, invasion and wound-healing assays were carried out. As shown in Fig. 2A, IL-8 increased the invasion of MDA-MB-231 cells as more cells stained by crystal violet were found on the bottom chambers of the Transwell membranes when compared with those in the control groups. BER $(90 \mu \mathrm{M})$ inhibited the invasion of MDA-MB-231 cells, and could abolish the increased cell invasion induced by IL- 8 .

In the wound-healing assays (Fig. 2B), BER (30, 60 and $90 \mu \mathrm{M})$ appeared to dose-dependently prevent the motility of MDA-MB-231 cells after treatment for 24 and $48 \mathrm{~h}$. However, IL-8 (100 ng/ml) treatment did not affect cell motility (Fig. 2C) at 24 or $48 \mathrm{~h}$ and showed no interaction with BER treatment.

BER inhibits gene expression of metastasis-related molecules in MDA-MB-231 cells. To confirm the anti-metastatic effect of BER, the mRNA expression of MMP-2, EGF, E-cadherin, bFGF and fibronectin was quantified by qPCR. BER at $90 \mu \mathrm{M}$ decreased the mRNA expression of the measured molecules significantly $(\mathrm{P}<0.05$ or $\mathrm{P}<0.001)$ (Fig. 3). By contrast, when used $<90 \mu \mathrm{M}$, BER only reduced the mRNA expression of MMP-2, EGF and fibronectin.

BER induces G2/M phase arrest and apoptosis in MDA-MB231 cells. BER induced the G2/M arrest of MDA-MB-231 cells in a dose-dependent manner (Fig. 4). IL-8 (100 ng/ml) had no effect on cell cycle distribution. When combined with IL-8, BER $(90 \mu \mathrm{M})$ induced $\mathrm{G} 2 / \mathrm{M}$ arrest significantly, although no difference with that induced by BER alone was observed.

BER appeared to dose-dependently induce the apoptosis of MDA-MB-231 cells as the ratio of early apoptotic cells increased with the elevation of BER concentrations (Fig. 5I). By contrast, as shown in Fig. 5II, IL-8 did not markedly affect cell apoptosis. To our surprise, it also did not influence cell apoptosis induced by $\operatorname{BER}(90 \mu \mathrm{M})$.

Consistent with the results from flow cytometry, BER modulated the expression of apoptotic proteins. BER dose-dependently increased the amount of cleaved caspase-3 (Fig. 5I). By contrast, it also downregulated the protein expression of Bcl-2 in a dose-dependent manner but showed no effect on the expression of Bax.

Cellular signaling pathways are involved in BER-induced apoptosis in MDA-MB-231 cells. To determine the effect of BER on the protein expression of the cellular signaling molecules, MDA-MB-231 cells were treated with BER (30, 60 and $90 \mu \mathrm{M}$ ) for $24 \mathrm{~h}$ and then subjected to western blot analysis. Fig. 6A shows that BER dose-dependently increased the phosphorylation of p38 and SAPK/JNK MAPKs but did not affect that of ERK. By contrast, BER treatment decreased the phosphorylation of Jak2, p85 PI3K, Akt and p65 NF- $\mathrm{B}$ in 


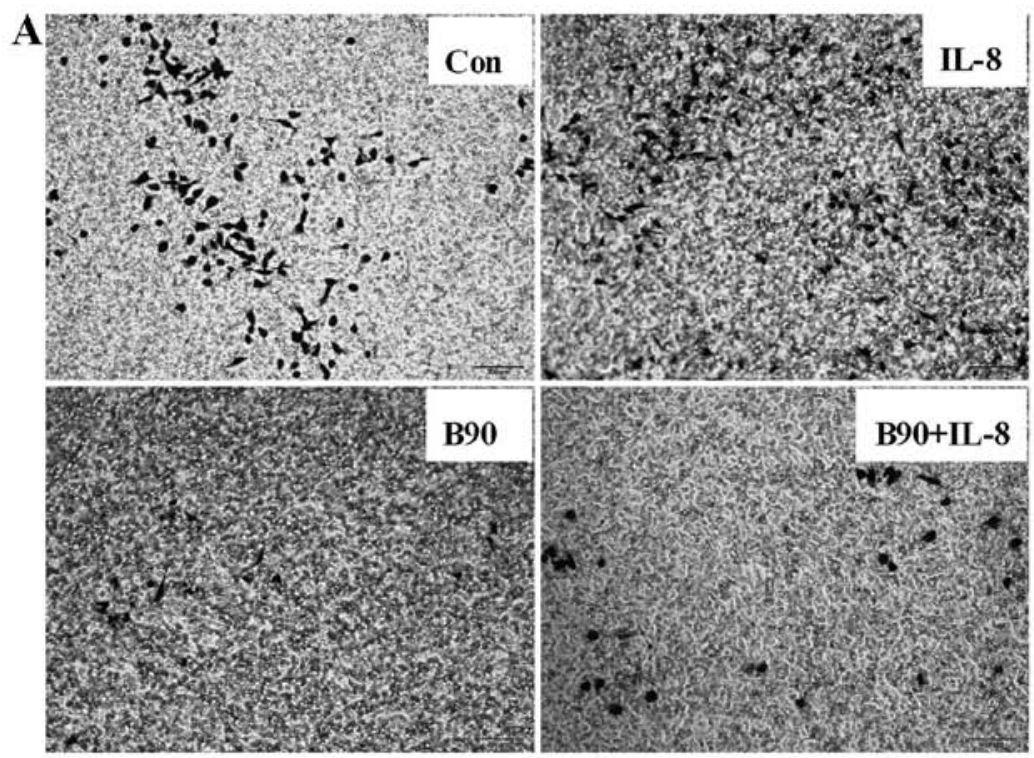

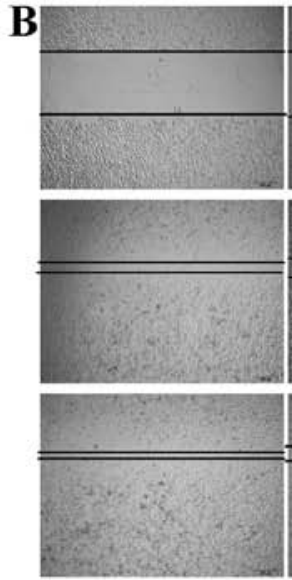

0

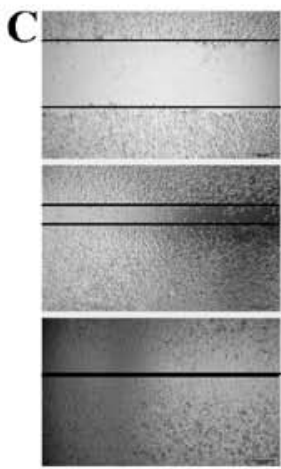

0

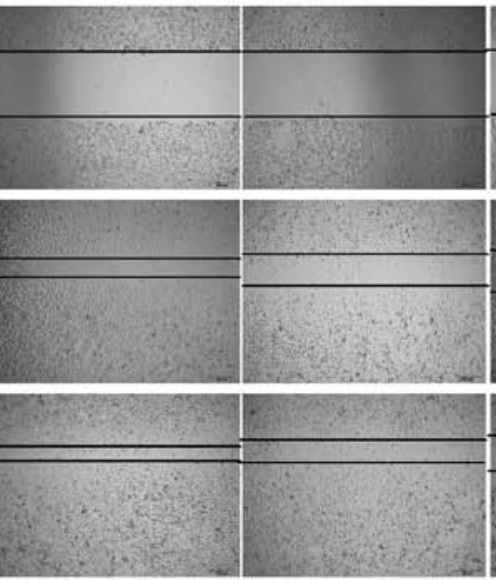

B30

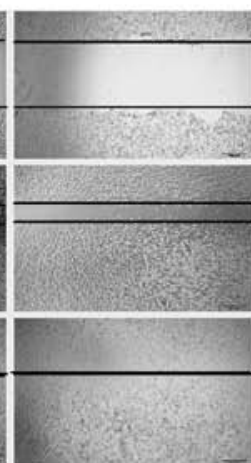

IL-8
B60

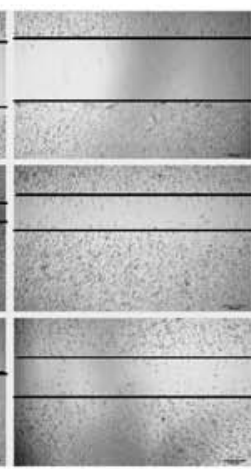

B90

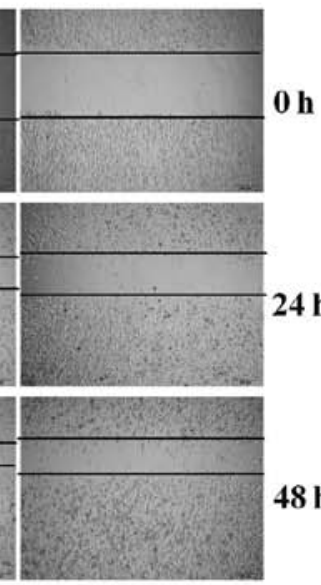

B90

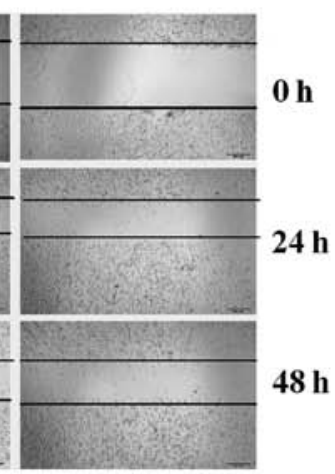

B90+ IL-8

Figure 2. BER inhibits cell invasion and migration in MDA-MB-231 cells. (A) IL-8 increased the cell invasion of MDA-MB-231 cells, and BER inhibited cell invasion and counteracted the increased cell invasion induced by IL-8, which was assessed by crystal violet staining. (B) BER inhibited the cell motility of MDA-MB-231 cells in a dose-dependent manner, as assessed by the wound-healing assay. (C) IL-8 (100 ng/ml) did not affect the cell motility of MDA-MB-231 cells, as assessed by the wound-healing assay. B, berberine hydrochloride.

a dose-dependent manner (Fig. 6B). Additionally, BER inhibited the mRNA expression of Jak2 and Akt1 (Fig. 6C and D).

To verify the involvement of p38 and JNK MAPKs in the BER-induced apoptosis, MAPK pathway inhibitors were used together with BER $(90 \mu \mathrm{M})$. As shown in Fig. 7A-G, the elevated apoptosis induced by BER was significantly abrogated by SB203580 and SP600125. Moreover, the addi- tion of SB203580 and SP600125 reduced the cellular cleaved caspase-3 compared with that treated with BER (Fig. 7H). To confirm the effect of p38 MAPK and JNK on BER-induced apoptosis, anisomycin, the $\mathrm{p} 38$ MAPK and JNK activator, was used. As shown in Fig. 8A, anisomycin $(10 \mu \mathrm{g} / \mathrm{ml})$ significantly increased the activation of $\mathrm{p} 38$ MAPK, which enhanced the cleavage of caspase-3. When co-treated with anisomycin, BER 
A

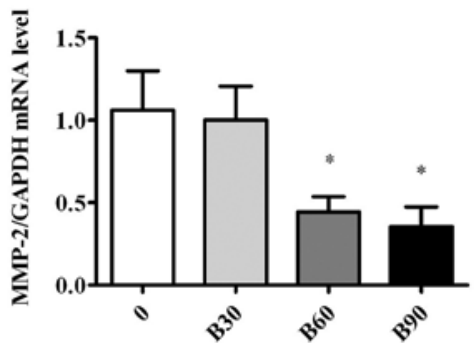

C

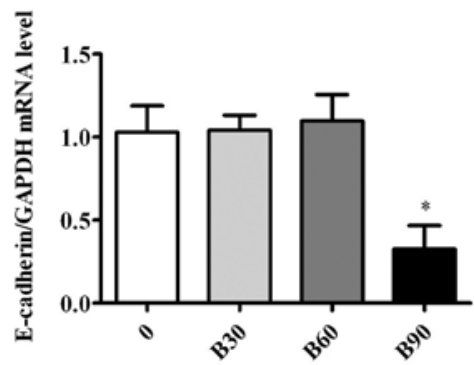

B

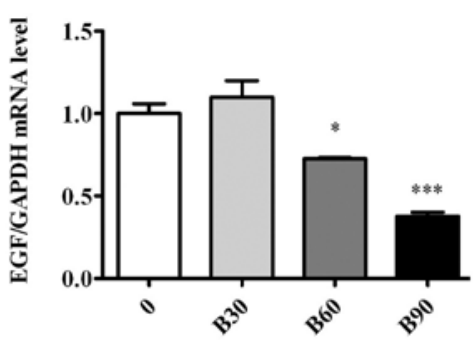

D

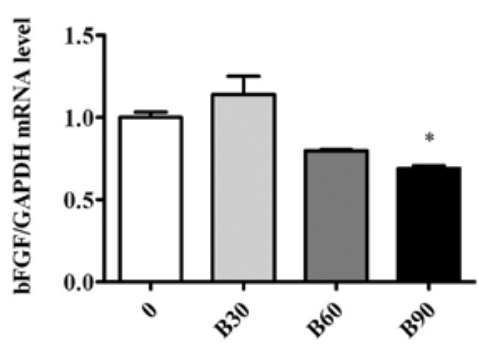

$\mathbf{E}$

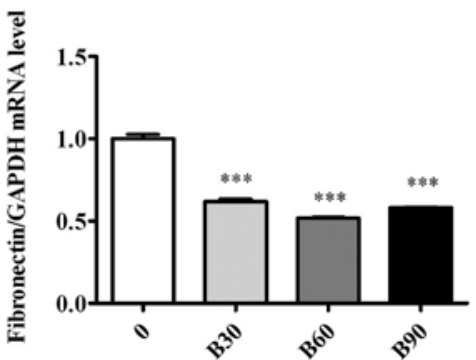

Figure 3. BER inhibits gene expression of metastasis-related proteins for $24 \mathrm{~h}$. Gene expression of MMP-2, EGF, E-cadherin, bFGF and fibronectin were all significantly downregulated by BER. Data are presented as means $\pm \mathrm{SEM},{ }^{*} \mathrm{P}<0.05,{ }^{* * * *} \mathrm{P}<0.001$ vs. control. $\mathrm{B}$, berberine hydrochloride.
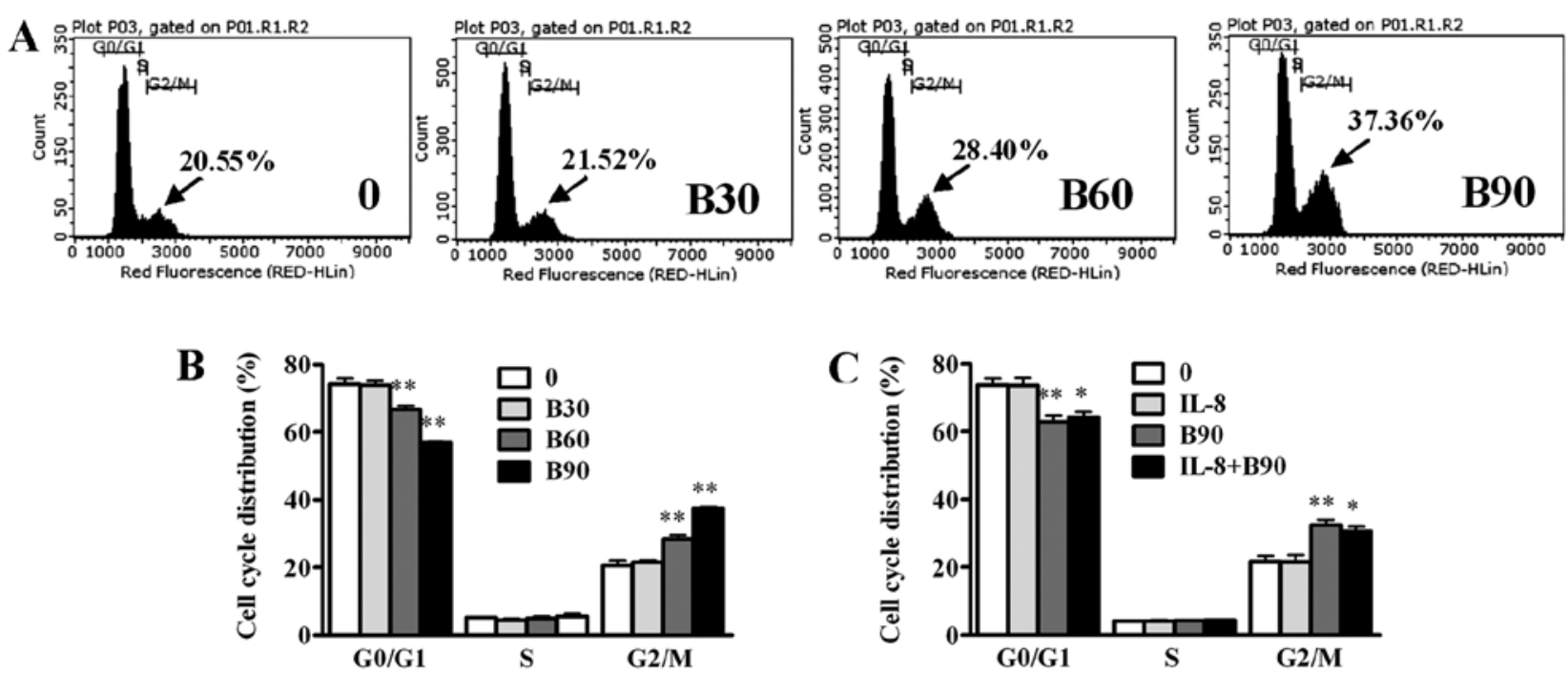

Figure 4. BER induces G2/M phase arrest in an IL-8 independent manner in MDA-MB-231 cells. (A) Typical images from flow cytometry with PI staining showed G2/M arrest. (B) BER induced G2/M arrest after treatment for $24 \mathrm{~h}$ detected by flow cytometry with PI staining. (C) BER induced G2/M phase arrest in an IL-8-independent manner. Data are presented as means $\pm \mathrm{SEM} ;{ }^{*} \mathrm{P}<0.05,{ }^{* *} \mathrm{P}<0.01$ vs. control. $\mathrm{B}$, berberine hydrochloride.

$(90 \mu \mathrm{M})$ induced the increased phosphorylation of $\mathrm{p} 38 \mathrm{MAPK}$ compared with BER treatment alone, leading to an increased production of cleaved caspase-3. Consistent with the western blot results, anisomycin and BER induced significant apoptosis compared with the control $(\mathrm{P}<0.001)($ Fig. $8 \mathrm{~B}-\mathrm{F})$. When combined together, anisomycin and BER enhanced apoptosis as compared to that induced individually.

In the present study, the effect of NF- $\mathrm{KB}, \mathrm{PI} 3 \mathrm{~K}, \mathrm{AP}-1$ and JAK2 on BER-induced apoptosis was clarified. As shown in Fig. 9, inhibitors of NF-KB and AP-1 increased the rates of 

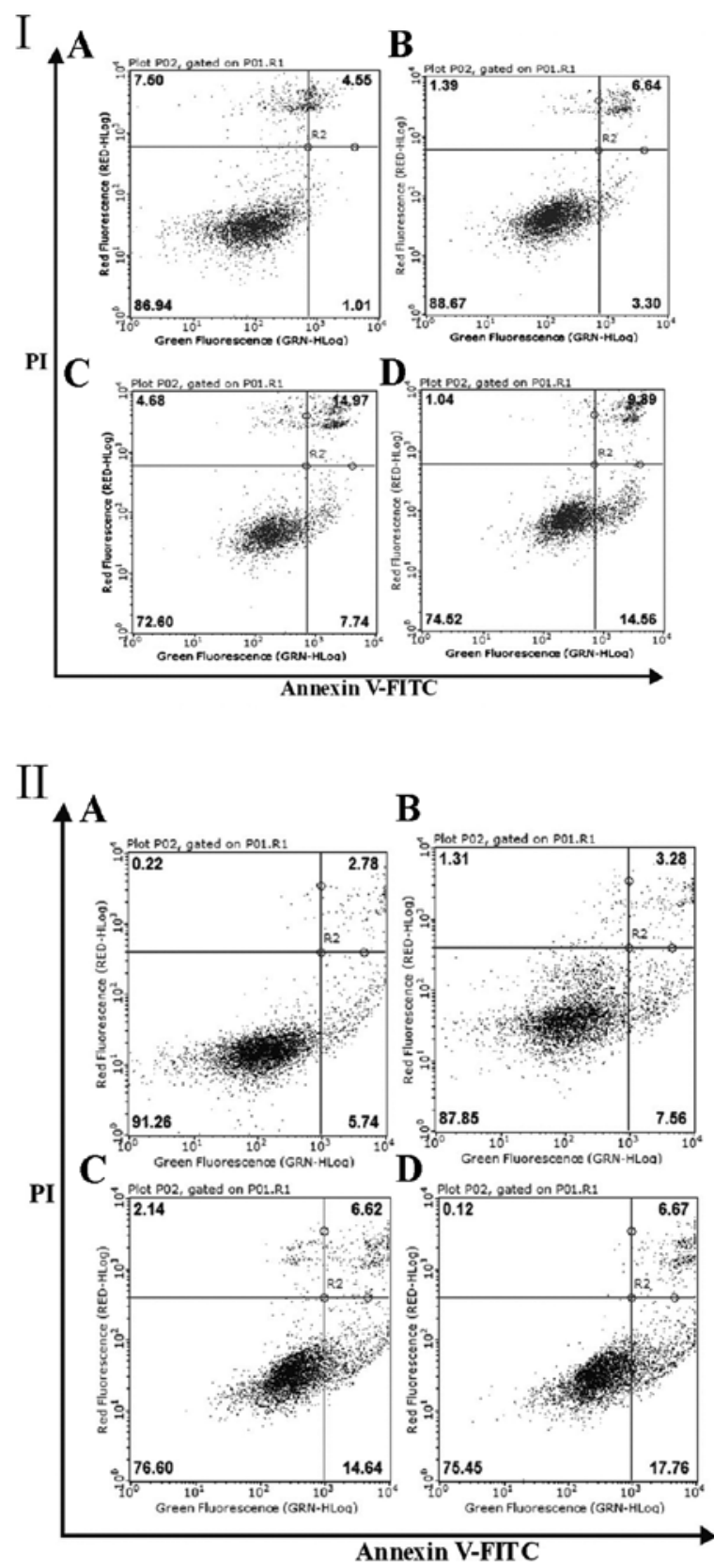

$\mathbf{E}$
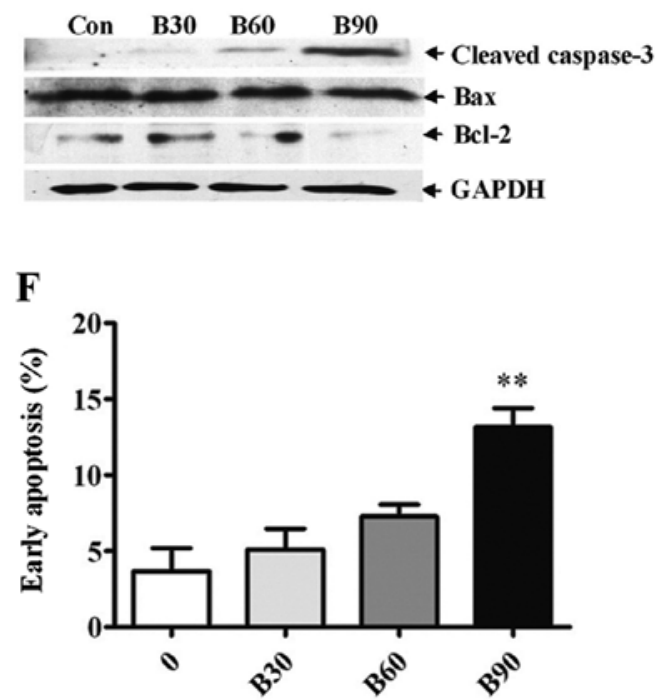

$\mathbf{E}$

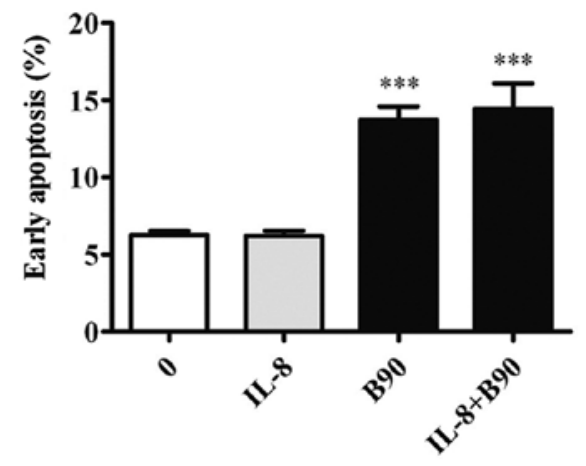

Figure 5. BER promotes cell apoptosis in MDA-MB-231 cells in an IL-8 independent manner. (I) BER promoted cell apoptosis in MDA-MB-231 cells through caspase- 3 and the mitochondrial-dependent pathway measured by Annexin V/PI double staining. (II) IL- 8 was not involved in enhancing cell apoptosis induced by berberine hydrochloride measured by Annexin V/PI double staining. Data are presented as means \pm SEM; ${ }^{* *} \mathrm{P}<0.01,{ }^{* * *} \mathrm{P}<0.001 \mathrm{vs}$. control. $\mathrm{B}$, berberine hydrochloride.

cell apoptosis. Pre-incubation with the inhibitors of $N F-\kappa B$, PI3K, AP-1 and JAK2 significantly increased cell apoptosis induced by BER. Moreover, the protein expression of cleaved caspase- 3 was increased by the pre-incubation of inhibitors of PI3K, JAK2 and p65 NF- $\mathrm{KB}$, compared with BER used alone.

\section{Discussion}

The results of the present study have demonstrated that BER significantly inhibited IL-8 secretion, invasion and migration of MDA-MB-231 cells and induced cell apoptosis. Additional experiments revealed that BER suppressed cell proliferation through G2/M arrest and promoted apoptosis of MDA-MB-231 cells by modulation of various signaling pathway molecules such as MAPKs, JAK2, PI3K, Akt and NF- $\mathrm{BB}$.

Chemotherapeutic agents are known to induce IL-8 upregulation in tumor cells, which is closely associated with chemotherapy resistance and cancer metastasis (3,5-7,10,18,21-25,37-40). Depletion of IL-8 induces cell cycle arrest and increases the efficacy of chemotherapeutic agents in breast cancer cells (41). Therefore, chemotherapeutic agents with an inhibitory effect on IL-8 production may be more efficacious in treating breast cancer. MDA-MB-231 is one of the breast cancer cell lines constitutively expressing a high level of IL-8 $(15,16)$. Consistent with previous studies (41), IL-8 enhanced the invasive ability of MDA-MB-231 cells in our 
A
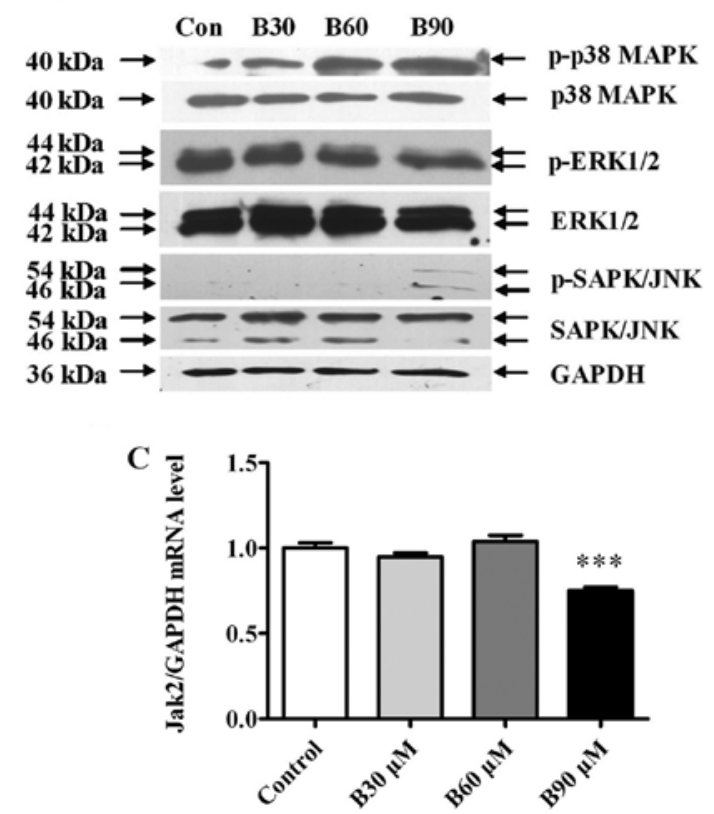

B

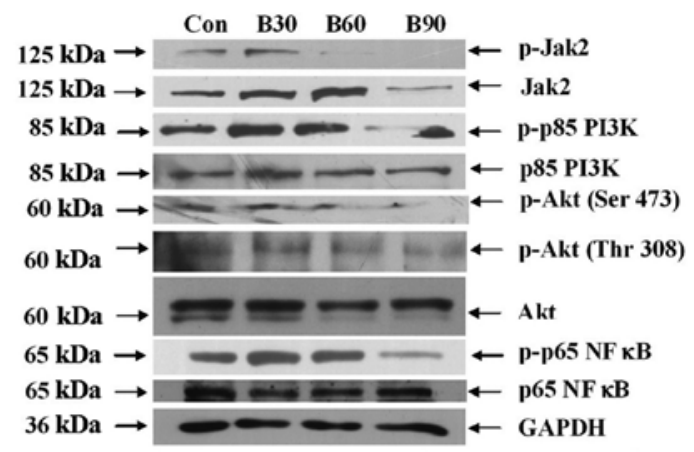

D

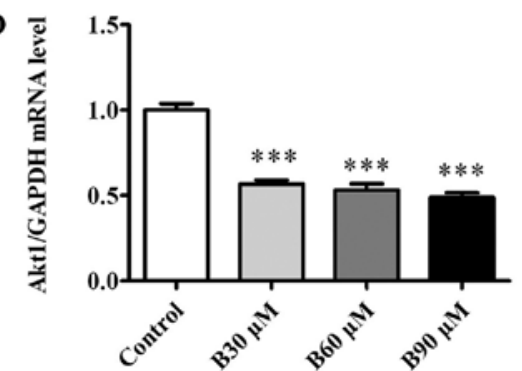

Figure 6. BER activates the p38 MAPK and JNK pathways, and inactivates the Jak2, p85 PI3K, Akt and p65 NF-kB pathways. (A) Western blotting results show that BER enhanced the phosphorylation of p38 MAPK and JNK. (B) Results from western blotting show that BER inhibited the phosphorylation of Jak2, p85 PI3K, Akt and p65 NF- $\mathrm{kB}$. (C and D) qPCR results showed that the gene expression of Jak2 and Akt1 was significantly downregulated by BER. Data are presented as means $\pm \mathrm{SEM} ;{ }^{* * *} \mathrm{P}<0.001$ vs. control. $\mathrm{B}$, berberine hydrochloride.
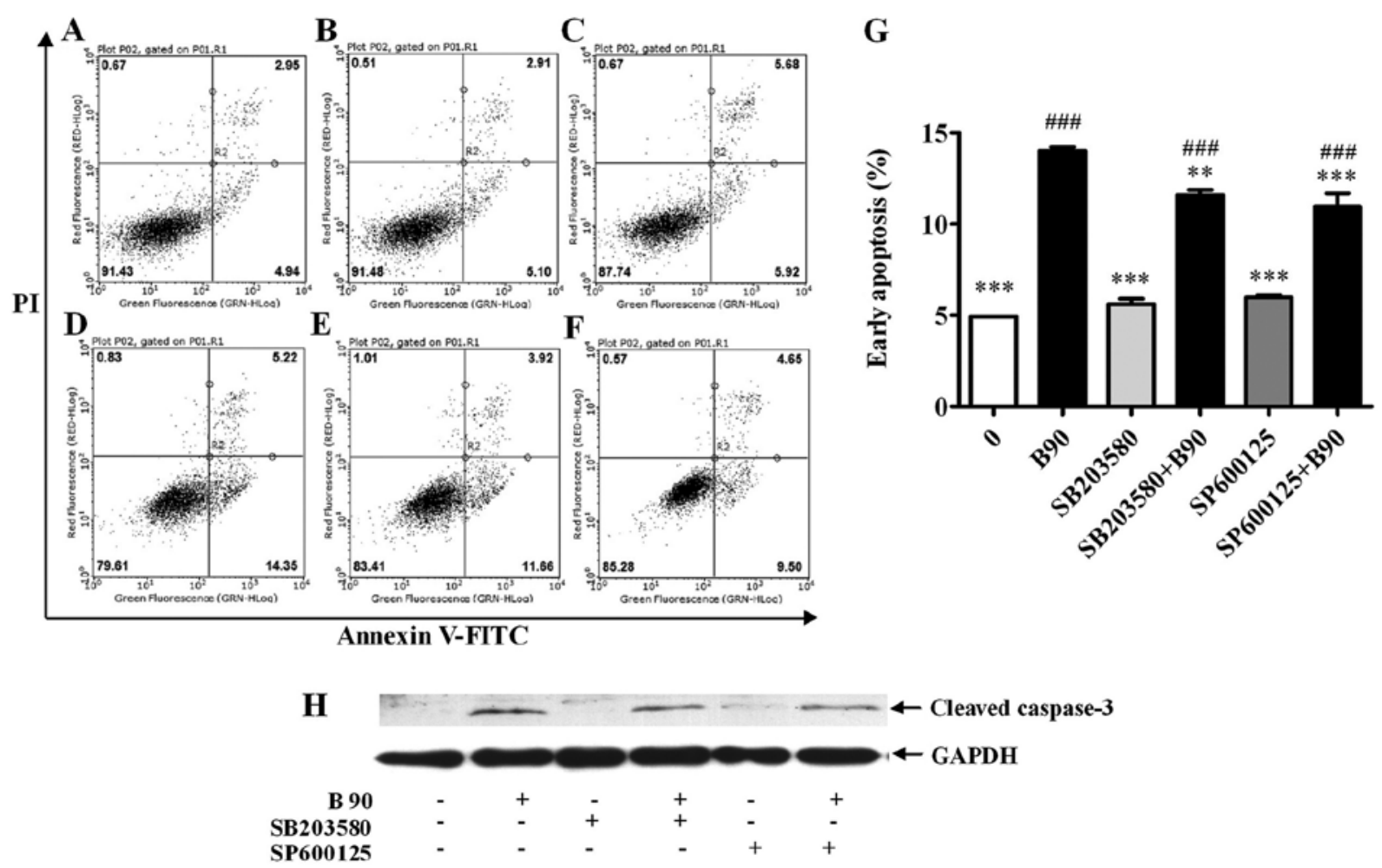

Figure 7. Blockage of p38 MAPK and JNK decreases cell apoptosis induced by BER in MDA-MB-231 cells. (A-F) Typical images from flow cytometry with Annexin V/PI double staining. (G) Blockage of p38 MAPK and JNK decreased cell apoptosis induced by BER. (H) Western blotting results showed that blockage of p38 MAPK and JNK decreased cleaved caspase- 3 expression induced by BER. Data are presented as means $\pm \mathrm{SEM} ;{ }^{* * *} \mathrm{P}<0.01,{ }^{* * *} \mathrm{P}<0.001 \mathrm{vs}$. control;

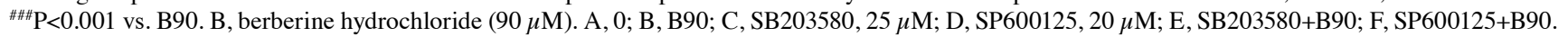

experiments (Fig. 2A). However, IL-8 did not interfere with cell migration (Fig. 2C) or cell cycle distribution (Fig. 4). To the best of our knowledge, IL-8 mainly increases the risk of breast cancer metastasis through the enhancement of invasive ability, at least, for MDA-MB-231 cells. In the present study, BER dose-dependently inhibited the proliferation and IL- 8 
A
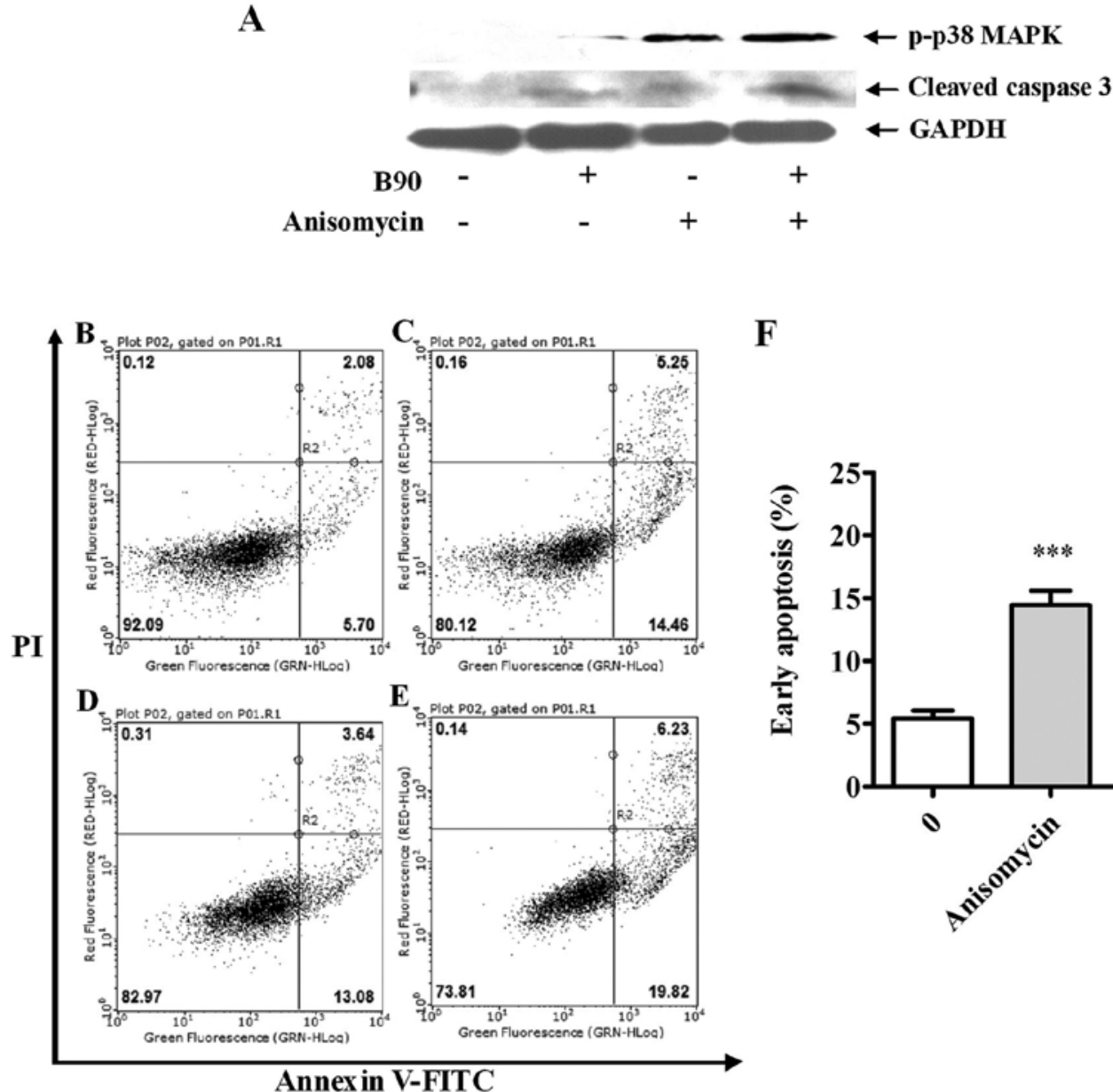

F

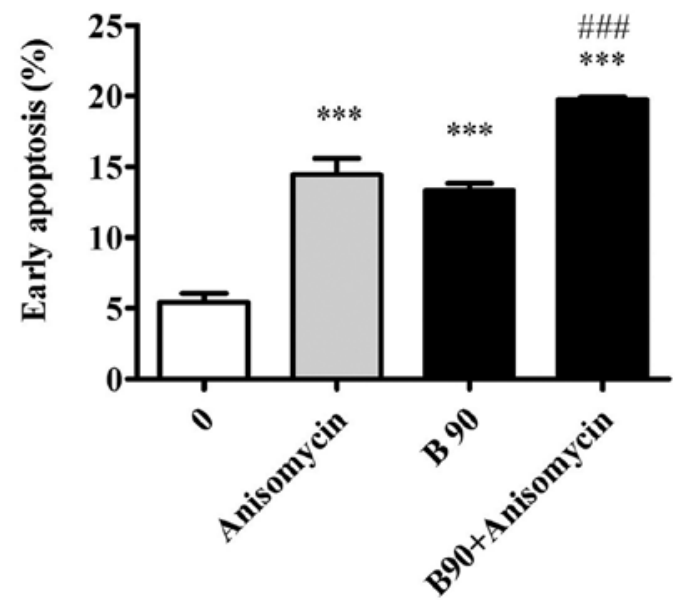

Figure 8. Activation of p38 MAPK increases cell apoptosis induced by BER in MDA-MB-231 cells. (A) Western blotting results showed that anisomycin enhanced the phosphorylation of p38 MAPK induced by BER. (B-E) Typical images from flow cytometry with Annexin V/PI double staining. (F) Activation of MAPK increased cell apoptosis induced by BER. Data are presented as means $\pm \mathrm{SEM} ;{ }^{* * *} \mathrm{P}<0.001$ vs. control; ${ }^{\# \# \#} \mathrm{P}<0.001$ vs. B90. B, berberine hydrochloride (90 $\mu \mathrm{M})$. B, 0; C, anisomycin, $10 \mu \mathrm{g} / \mathrm{ml}$; D, B90; E, B90 + anisomycin.

secretion of MDA-MB-231 cells (Fig. 1B and C). Furthermore, BER abrogated the increased invasion induced by IL- 8 . Thus, BER counteracted the metastasis of MDA-MB-231 cells at least partly in an IL-8 dependent manner.

A number of pathways have been found to be actively involved in the modulation of IL- 8 production, including MAPKs, JAK2, and PI3K/Akt pathways (21,25,42-44). In agreement with those studies, our results showed that the activation of ERK1/2, SAPK/JNK, p38 MAPK, JAK2, p85 PI3K, AP-1 and p65 NF- $\kappa$ B pathways was closely associated with the constitutive IL-8 secretion in MDA-MB-231 cells (Fig. 1D). Correspondingly, BER was able to modulate the activation of those molecules. Notably, BER only deactivated JAK2, p85 PI3K and p65 NF- $\mathrm{KB}$ signaling but activated that of MAPK pathway molecules (Fig. 6). Therefore, the inhibition of BER on IL-8 production might occur mainly through JAK2/PI3K/ $\mathrm{NF}-\kappa \mathrm{B}$ pathways.

IL-8 can activate PI3K, protein kinase B (PKB and Akt), mammalian target of rapamycin (mTOR), ERK1/2, p38 MAPK and JAK2 pathways to regulate numerous gene and protein expressions involved in cell proliferation, survival, invasion and migration $(25,45)$. Activation of PI3K and JAK2 pathways has been reported to modulate cell invasion and angiogenesis (25). In experiments of the present study, we found that BER inactivated the PI3K/Akt, JAK2 and NF- $\kappa \mathrm{B}$ pathways. The results also showed that many metastasis-related genes, including MMP-2, EGF, E-cadherin, bFGF and fibronectin, were downregulated by BER, suggesting the anti-invasive effect of BER was partly, if not all, mediated in an IL-8 dependent manner.

IL-8 was also found to be independent of cell migration, cell cycle distribution and apoptosis of MDA-MB-231 cells. By contrast, BER was actively engaged in these processes, which inhibited cell migration, and induced G2/M arrest and cell apoptosis in an IL-8 independent manner.

The mitogen-activated protein kinases (MAPK) pathways, i.e., ERK, SAPK/JNK and p38 MAPK, are actively involved in drug-induced cell apoptosis of numerous cancer cells (46). Activation of JNK and 338 MAPK pathways results in enhanced apoptosis induced by berberine in human hepatoma and colon carcinoma cells $(34,35)$. When the MAPKs are inhibited, the apoptosis and caspase-3 cleavage in tumor cells are abrogated (46-48). Moreover, inhibitors of MAPKs slightly increase cell viability in MDA-MB-231 cells (49). In the present study, the phosphorylation of p38 MAPK and SAPK/JNK was enhanced by BER treatment. In agreement with the previous studies $(31,34)$, the inhibitors of p38 MAPK and SAPK/JNK attenuated the apoptosis enhanced by BER treatment in a caspase-3-dependent manner, while the inhibitors of $\mathrm{p} 38 \mathrm{MAPK}$ and SAPK/JNK 
A
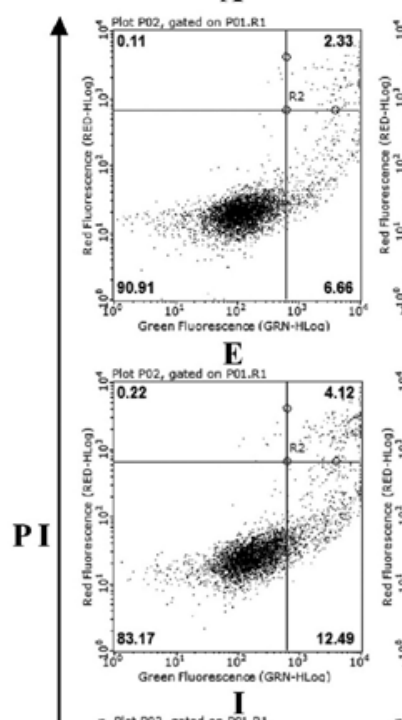

I

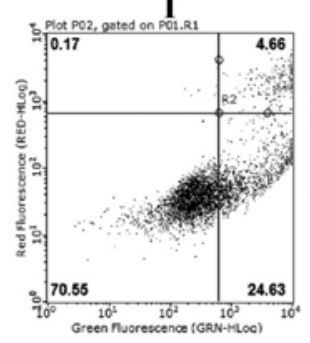

B

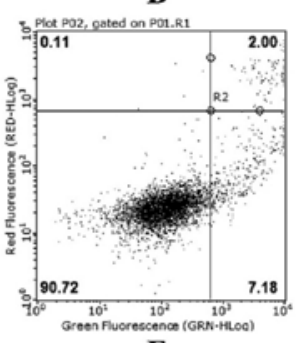

F

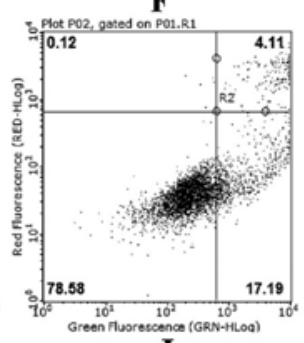

J

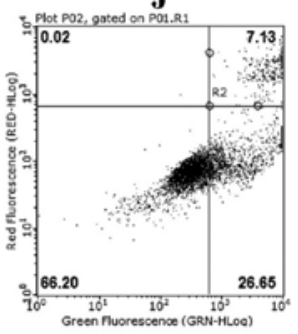

C

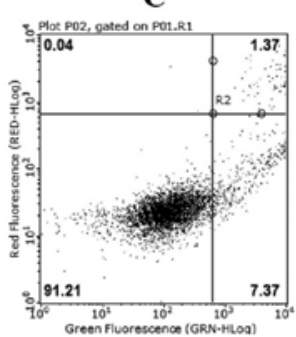

G

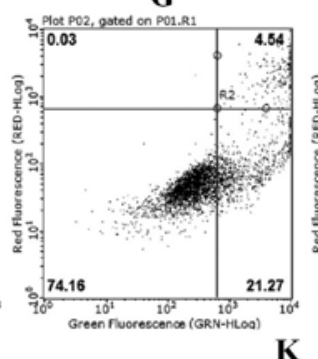

K

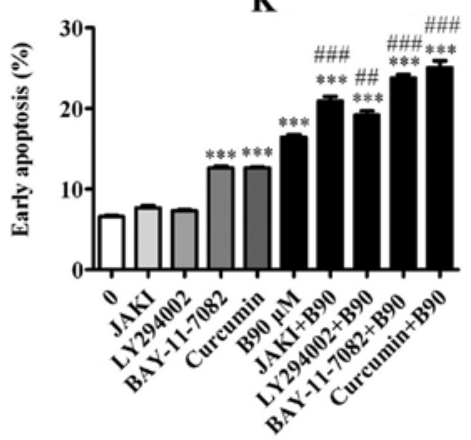

D

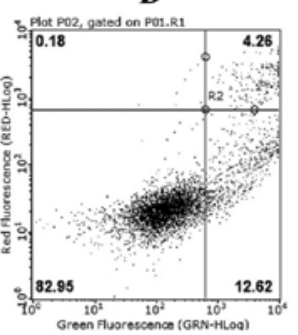

H

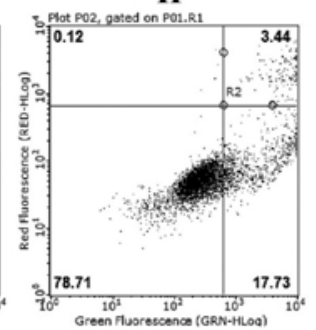

Annexin V-FITC

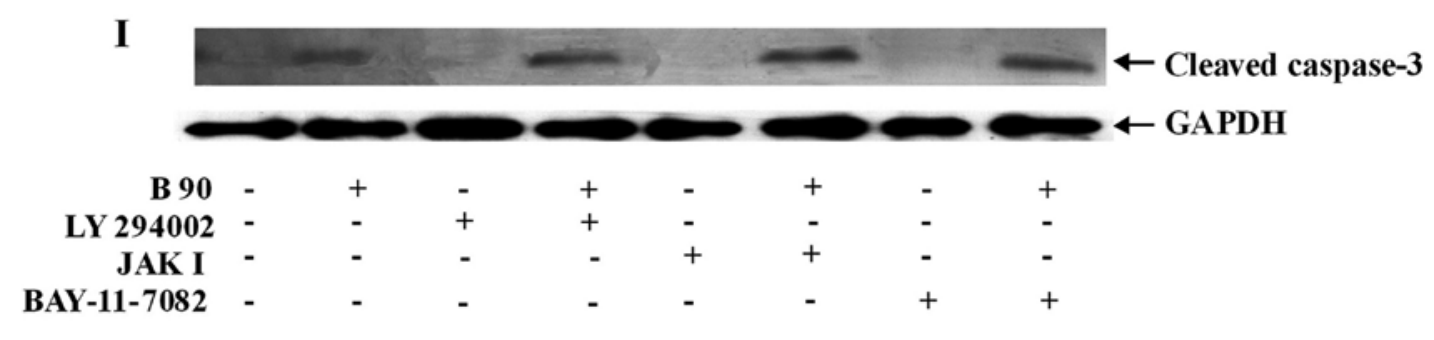

Figure 9. Blockage of PI3K, Jak2, NF- $\mathrm{KB}$ and AP-1 elevates cell apoptosis induced by BER in MDA-MB-231 cells. (A-J) Typical images from flow cytometry with Annexin V/PI double staining. (K) Blockage of PI3K, Jak2, NF-kB and AP-1 elevated cell apoptosis induced by BER in MDA-MB-231 cells. (I) Western blotting results showed that the blockage of PI3K, Jak2 and NF- $\mathrm{KB}$ increased cleaved caspase- 3 expression induced by BER. Data are presented as means \pm SEM; ${ }^{* * *} \mathrm{P}<0.001$ vs. control; ${ }^{\# \#} \mathrm{P}<0.01,{ }^{\# \# \#} \mathrm{P}<0.001$ vs. B90. B90, berberine hydrochloride $(90 \mu \mathrm{M})$. A, 0; B, JAK I, $5 \mu$; C, LY294002, $10 \mu \mathrm{M} ; \mathrm{D}, \mathrm{BAY}-11-7082,5 \mu \mathrm{M}$; E, Curcumin, $8 \mu$ M; F, B90; G, JAKI+B90; H, LY294002+B90; I, BAY-11-7082+B90; J, Curcumin+B90.

alone showed no obvious effect on cell apoptosis in MDA-MB231 cells. Furthermore, anisomycin, an activator of p38 MAPK and JNK, induced cell apoptosis and significantly elevated cell apoptosis induced by BER in a caspase-3-dependent manner. Thus, the activation of $\mathrm{p} 38 \mathrm{MAPK}$ and SAPK/JNK was involved in the cell apoptosis induced by BER.

In breast cancer cells, activation of the PI3K/Akt pathway has already been found to prevent cell apoptosis $(27,36)$. By contrast, inhibition of janus kinase 2 (JAK2) promotes cell apoptosis $(51,52)$. However, the effect of JAK2 on apoptosis induced by BER remains to be clarified. In the present study, BER inhibited the activation of JAK2, p85 PI3K and Akt by reducing the phosphorylation of Jak2, p85 PI3K and Akt1. Moreover, the inhibitors of NF- $\mathrm{kB}, \mathrm{PI} 3 \mathrm{~K}$ and JAK2 enhanced the cell apoptosis induced by BER, suggesting the involvement of these three pathways in the BER-induced apoptosis of MDA-MB-231 cells. The gene expression of total Jak2 and Akt1 was also decreased by BER. Therefore, the enhanced apoptosis induced by BER resulted from crosstalk among multiple cell signaling pathways including p38 MAPK, JNK, $\mathrm{PI} 3 \mathrm{~K} / \mathrm{Akt} / \mathrm{NF}-\mathrm{kB}$ and JAK2.

In conclusion, BER inhibited cell metastasis partly through the downregulation of IL-8 and enhanced cell apoptosis by activating MAPKs and deactivating the JAK2/PI3K/Akt/ NF- $\kappa B$ pathways. This was different from other chemotherapeutic drugs that induce apoptosis but simultaneously increase IL-8 expression, therefore, promote cancer metastasis. Thus, BER showed simultaneous anti-carcinoma in situ and anti- 
metastatic effects in MDA-MB-231 cells, suggesting the effective and safe potential of BER as a therapeutic candidate to treat highly metastatic breast cancer.

\section{Acknowledgements}

The present study was supported by the Educational Commission of Shanghai of China (2012JW19); the Key Research Innovation Project (13ZZ099); the Key Project from the Department of Education of China (20123107130002); the Shanghai Eastern Scholar Program (2013-59); and the Excellent Research Team Cultivation Program of Shanghai University of Traditional Chinese Medicine.

\section{References}

1. Siegel R, Naishadham D and Jemal A: Cancer statistics. CA Cancer J Clin 62: 10-29, 2012.

2. Jemal A, Bray F, Center MM, Ferlay J, Ward E and Forman D: Global cancer statistics. CA Cancer J Clin 61: 69-90, 2011.

3. Kuai WX, Wang Q, Yang XZ, Zhao Y, Yu R and Tang XJ: Interleukin-8 associates with adhesion, migration, invasion and chemosensitivity of human gastric cancer cells. World $\mathbf{J}$ Gastroenterol 18: 979-985, 2012

4. Bünger S, Haug U, Kelly FM, Klempt-Giessing K, Cartwright A, Posorski N, Dibbelt L, Fitzgerald SP, Bruch HP, Roblick UJ, von Eggeling $\mathrm{F}$, Brenner $\mathrm{H}$, Habermann JK and BMBFConsortium 'Colorectal Cancer Screening Chip': Toward standardized high-throughput serum diagnostics: multiplexprotein array identifies IL-8 and VEGF as serum markers for colon cancer. J Biomol Screen 16: 1018-1026, 2011.

5. Kitadai Y, Takahashi Y, Haruma K, Naka K, Sumii K, Yokozaki H, Yasui W, Mukaida N, Ohmoto Y and Kajiyama G: Transfection of interleukin-8 increases angiogenesis and tumorigenesis of human gastric carcinoma cells in nude mice. $\mathrm{Br} \mathrm{J}$ Cancer 81: 647-653, 1999.

6. Matsuo Y, Ochi N, Sawai H, Yasuda A, Takahashi H, Funahashi H, Takeyama H, Tong $\mathrm{Z}$ and Guha S: CXCL8/IL-8 and CXCL12/SDF-1alpha co-operatively promote invasiveness and angiogenesis in pancreatic cancer. Int J Cancer 124: 853-861, 2009.

7. Ju D, Sun D, Xiu L, Meng X, Zhang C and Wei P: Interleukin-8 is associated with adhesion, migration and invasion in human gastric cancer SCG-7901 cells. Med Oncol 29: 91-99, 2012.

8. Mohamed MM: Monocytes conditioned media stimulate fibronectin expression and spreading of inflammatory breast cancer cells in three-dimensional culture: a mechanism mediated by IL-8 signaling pathway. Cell Commun Signal 10: 3, 2012.

9. Asfaha S, Dubeykovskiy AN, Tomita H, Yang X, Stokes S, Shibata W, Friedman RA, Ariyama H, Dubeykovskaya ZA, Muthupalani S, Ericksen R, Frucht H, Fox JG and Wang TC: Mice that express human interleukin-8 have increased mobilization of immature myeloid cells, which exacerbates inflammation and accelerates colon carcinogenesis. Gastroenterology 144: 155-166, 2013

10. Shi HL, Wu XJ, Liu Y and Xie JQ: Berberine counteracts enhanced IL-8 expression of AGS cells induced by evodiamine. Life Sci 93: 830-839, 2013.

11. Milovanovic J, Todorovic-Rakovic N and Abu Rabi Z: The prognostic role of interleukin-8 (IL-8) and matrix metalloproteinases -2 and -9 in lymph node-negative untreated breast cancer patients. J BUON 18: 866-873, 2013.

12. Hartman ZC, Poage GM, den Hollander P, Tsimelzon A, Hill J, Panupinthu N, Zhang Y, Mazumdar A, Hilsenbeck SG, Mills GB and Brown PH: Growth of triple-negative breast cancer cells relies upon coordinate autocrine expression of the proinflammatory cytokines IL-6 and IL-8. Cancer Res 73: 3470-3480, 2013.

13. Singh JK, Farnie G, Bundred NJ, Simões BM, Shergill A, Landberg G, Howell SJ and Clarke RB: Targeting CXCR1/2 significantly reduces breast cancer stem cell activity and increases the efficacy of inhibiting HER2 via HER2-dependent and -independent mechanisms. Clin Cancer Res 19: 643-656, 2013.

14. Todorović-Raković $\mathrm{N}$ and Milovanović J: Interleukin-8 in breast cancer progression. J Interferon Cytokine Res 33: 563-570, 2013.
15. Freund A, Chauveau C, Brouillet JP, Lucas A, Lacroix M, Licznar A, Vignon F and Lazennec G: IL-8 expression and its possible relationship with estrogen-receptor-negative status of breast cancer cells. Oncogene 22: 256-265, 2003.

16. Freund A, Jolivel V, Durand S, Kersual N, Chalbos D, Chavey C, Vignon F and Lazennec G: Mechanisms underlying differential expression of interleukin-8 in breast cancer cells. Oncogene 23: 6105-6114, 2004.

17. Neve RM, Chin K, Fridlyand J, Yeh J, Baehner FL, Fevr T, Clark L, Bayani N, Coppe JP, Tong F, Speed T, Spellman PT, DeVries S, Lapuk A, Wang NJ, Kuo WL, Stilwell JL, Pinkel D, Albertson DG, Waldman FM, McCormick F, Dickson RB, Johnson MD, Lippman M, Ethier S, Gazdar A and Gray JW: A collection of breast cancer cell lines for the study of functionally distinct cancer subtypes. Cancer Cell 10: 515-527, 2006.

18. Britschgi A, Andraos R, Brinkhaus H, Klebba I, Romanet V, Müller U, Murakami M, Radimerski T and Bentires-Alj M: JAK2/STAT5 inhibition circumvents resistance to PI3K/Mtor blockade: a rationale for cotargeting these pathways in metastatic breast cancer. Cancer Cell 22: 796-811, 2012

19. Shi Z, Yang WM, Chen LP, Yang DH, Zhou Q, Zhu J, Chen JJ, Huang RC, Chen ZS and Huang RP: Enhanced chemosensitization in multidrug-resistant human breast cancer cells by inhibition of IL- 6 and IL-8 production. Breast Cancer Res Treat 135: 737-747, 2012.

20. Juvekar A and Wulf GM: Closing escape routes: inhibition of IL-8 signaling enhances the anti-tumor efficacy of PI3K inhibitors. Breast Cancer Res 15: 308, 2013.

21. Collins TS, Lee LF and Ting JP: Paclitaxel up-regulates interleukin-8 synthesis in human lung carcinoma through an NF-kappaB-and AP-1-dependent mechanism. Cancer Immunol Immunother 49: 78-84, 2000.

22. De Larco JE, Wuertz BR, Manivel JC and Furcht LT: Progression and enhancement of metastatic potential after exposure of tumor cells to chemotherapeutic agents. Cancer Res 61: 2857-2861, 2001.

23. Lev DC, Onn A, Melinkova VO, Miller C, Stone V, Ruiz M, McGary EC, Ananthaswamy HN, Price JE and Bar-Eli M: Exposure of melanoma cells to dacarbazine results in enhanced tumor growth and metastasis in vivo. J Clin Oncol 22: 2092-2100, 2004.

24. Kishida O, Miyazaki Y, Murayama Y, Ogasa M, Miyazaki T, Yamamoto T, Watabe K, Tsutsui S, Kiyahara T, Shimomura I and Shinomura Y: Gefitinib (Iressa, ZD1839) inhibits SN38-triggered EGF signals and IL-8 production in gastric cancer cells. Cancer Chemother Pharmacol 55: 584-594, 2005.

25. Waugh DJ and Wilson C: The interleukin-8 pathway in cancer. Clin Cancer Res 14: 6735-6741, 2008.

26. Kang JX, Liu J, Wang J, He C and Li FP: The extract of huanglian, a medicinal herb, induces cell growth arrest and apoptosis by upregulation of interferon-beta and TNF-alpha in human breast cancer cells. Carcinogenesis 26: 1934-1939, 2005.

27. Kuo HP, Chuang TC, Tsai SC, Tseng HH, Hsu SC, Chen YC, Kuo CL, Kuo YH, Liu JY and Kao MC: Berberine, an isoquinoline alkaloid, inhibits the metastatic potential of breast cancer cells via Akt pathway modulation. J Agric Food Chem 60: 9649-9658, 2012

28. Tan W, Li Y, Chen M and Wang Y: Berberine hydrochloride: anticancer activity and nanoparticulate delivery system. Int J Nanomed 6: 1773-1777, 2011

29. Yu HM, Peng QX, Liu TS, Yang DJ and Chen XZ: Effect of retro-Zuojin pill on apoptosis and Bcl-2, Bax gene expression in SGC-7901 cells. Chin J Exp Trad Med Form (Chin) 14: 28-31, 2008.

30. Shi HL, Xie JQ and Wu DZ: Effect of berberine on cell proliferation and IL-8 expression in AGS cells. Pharmacol Clin Chin Mater Med (Chin) 28: 45-48, 2012.

31. Hsu WH, Hsieh YS, Kuo HC, Teng CY, Huang HI, Wang CJ, Yang SF, Liou YS and Kuo WH: Berberine induces apoptosis in SW620 human colonic carcinoma cells through generation of reactive oxygen species and activation of JNK/p38 MAPK and Fas L. Arch Toxicol 81: 719-728, 2007.

32. Hur JM, Hyun MS, Lim SY, Lee WY and Kim D: The combination of berberine and irradiation enhances anti-cancer effects via activation of $\mathrm{p} 38$ MAPK pathway and ROS generation in human hepatoma cells. J Cell Biochem 107: 955-964, 2009.

33. Kuo HP, Chuang TC, Yeh MH, Hsu SC, Way TD, Chen PY, Wang SS, Chang YH, Kao MC and Liu JY: Growth suppression of HER2-overexpressing breast cancer cells by berberine via modulation of the HER2/PI3K/Akt signaling pathway. J Agric Food Chem 59: 8216-8224, 2011. 
34. Ho YT, Lu CC, Yang JS, Chiang JH, Li TC, Ip SW, Hsia TC, Liao CL, Lin JG, Wood WG and Chung JG: Berberine induced apoptosis via promoting the expression of caspase- $8,-9$ and -3 , apoptosis-inducing factor and endonuclease G in SCC-4 human tongue squamous carcinoma cancer cells. Anticancer Res 29: 4063-4070, 2009.

35. Eom KS, Kim HJ, So HS, Park R and Kim TY: Berberineinduced apoptosis in human glioblastoma T98G cells is mediated by endoplasmic reticulum stress accompanying reactive oxygen species and mitochondrial dysfunction. Biol Pharm Bull 33: $1644-1649,2010$.

36. Xu LN, Lu BN, Hu MM, Xu YW, Han X, Qi Y and Peng JY: Mechanisms involved in the cytotoxic effects of berberine on human colon cancer HCT-8 cells. Biocell 36: 113-120, 2012.

37. Ebos JM,Lee CR, Cruz-Munoz W, Bjarnason GA, Christensen JG and Kerbel RS: Accelerated metastasis after short-term treatment with a potent inhibitor of tumor angiogenesis. Cancer Cell 15: 232-239, 2009.

38. Paez-Ribes M, Allen E, Hudock J, Takeda T, Okuyama H, Vinals F, Inoue M, Bergers G, Hanahan D and Casanovas O: Antiangiogenic therapy elicits malignant progression of tumors to increased local invasion and distant metastasis. Cancer Cell 15: 220-231, 2009.

39. Britschgi A, Radimerski $\mathrm{T}$ and Bentires-Alj M: Targeting PI3K, HER 2 and the IL-8/JAK2 axis in metastatic breast cancer: which combination makes the whole greater than the sum of its parts? Drug Resist Updat 16: 68-72, 2013.

40. Lai Y, Shen Y, Liu XH, Zhang Y, Zeng Y and Liu YF: Interleukin-8 induces the endothelial cell migration through the activation of phosphoinositide 3-kinase-Rac1/RhoA pathway. Int J Biol Sci 7: 782-791, 2011.

41. Shao N, Chen LH, Ye RY, Lin Y and Wang SM: The depletion of interleukin-8 causes cell cycle arrest and increases the efficacy of docetaxel in breast cancer cells. Biochem Biophys Res Commun 431: 535-541, 2013.

42. Chelouche-Lev D, Miller CP, Tellez C, Ruiz M, Bar-Eli M and Price JE: Different signalling pathways regulate VEGF and IL-8 expression in breast cancer: implications for therapy. Eur $\mathbf{J}$ Cancer 40: 2509-2518, 2004.

43. Bezzerri V, Borgatti M, Finotti A, Tamanini A, Gambari R and Cabrini G: Mapping the transcriptional machinery of the IL-8 gene in human bronchial epithelial cells. J Immunol 187: 6069-6081, 2011.
44. Wang Y, Wang W, Wang L, Wang X and Xia J: Regulatory mechanisms of interleukin-8 production induced by tumour necrosis factor- $\alpha$ in human hepatocellular carcinoma cells. J Cell Mol Med 16: 496-506, 2012.

45. Burger M, Hartmann T, Burger JA and Schraufstatter IU: KSHV-GPCR and CXCR 2 transforming capacity and angiogenic responses are mediated through a JAK2-3-dependent pathway. Oncogene 24: 2067-2075, 2005.

46. Uehara N, Kanematsu S, Miki H, Yoshizawa K and Tsubura A: Requirement of $\mathrm{p} 38$ MAPK for a cell-death pathway triggered by vorinostat in MDA-MB-231 human breast cancer cells. Cancer Lett 315: 112-121, 2012.

47. Kim YK, Kim HJ, Kwon CH, Kim JH, Woo JS, Jung JS and Kim JM: Role of ERK activation in cisplatin-induced apoptosis in OK renal epithelial cells. J Appl Toxicol 25: 374-382, 2005.

48. Jo SK, Cho WY, Sung SA, Kim HK and Won NH: MEK inhibitor, U0126, attenuates cisplatin-induced renal injury by decreasing inflammation and apoptosis. Kidney Int 67: 458-466, 2005.

49. Jayasooriya RGPT, Moon DO, Park SR, Choi YH, Asami Y, Kim MO, Jang JH, Kim BY, Ahn JS and Kim GY: Combined treatment with verrucarin A and tumor necrosis factor- $\alpha$ sensitizes apoptosis by overexpression of nuclear factor-kappaBmediated Fas. Envir Toxicol Pharmacol 36: 303-310, 2013.

50. Parada E, Egea J, Romero A, del Barrio L, García AG and López MG: Poststress treatment with PNU282987 can rescue SH-SY5Y cells undergoing apoptosis via $\alpha 7$ nicotinic receptors linked to a Jak2/Akt/HO-1 signaling pathway. Free Radic Biol Med 49: 1815-1821, 2010.

51. Chen Q, Lu Z, Jin Y, Wu Y and Pan J: Triptolide inhibits Jak2 transcription and induces apoptosis in human myeloproliferative disorder cells bearing Jak2V617F through caspase-3-mediated cleavage of Mcl-1. Cancer Lett 291: 246-255, 2010.

52. Will B, Siddiqi T, Jorda MA, Shimamura T, Luptakova K, Staber PB, Costa DB, Steidl U, Tenen DG and Kobayashi S: Apoptosis induced by JAK2 inhibition is mediated by Bim and enhanced by the BH3 mimetic ABT-737 in JAK2 mutant human erythroid cells. Blood 115: 2901-2909, 2010. 